\title{
Innovative Teaching in Political Science: 2000 Rowman \& Littlefield Award Winner Mark A. Boyer
}

As described in a December 2, 1996 issue of U.S. News \& World Report cover article on innovative uses of computers in the classroom,

\begin{abstract}
arms control diplomats from Russia generally don't wear flannel shirts, baseball hats and sneakers during work hours. They probably don't bring Ring Dings and pretzels to international summits. But these six "Russian" weapons experts are students role playing in a Global Education class at Windsor [Connecticut] High. Since they conduct negotiations via modem, appearance and eating habits hardly matter.
\end{abstract}

These students were getting an interactive glimpse of the real world and a hefty dose of computers which they didn't get in other classes. Behind the brief vignette lies the University of Connecticut's Connecticut Project in International Negotiation (CPIN) and a hint of its director's genius for integrating technology and research in the classroom.

Mark Boyer has devoted much of his political science teaching career to developing active learning approaches for international relations. To do justice to the impressive credentials of this year's winner of the fourth Rowman \& Littlefield Award for Innovative Teaching in Political Science, you would either have to sit in on one of Boyer's many classrooms, participate in one of his high school or middle school negotiation simulations, or visit his various web sites. Illustrative web site citations seem the most practical way of noting Boyer's many pedagogical accomplishments which have been lauded by his students and colleagues in UConn's department of political science, Neag School of Education, and College of Liberal Arts and Sciences.

Evidence of his leadership in the use of technology can be seen in his Introduction to International Relations (www.lib.uconn.edu/ $\sim$ mboyer/syl132.htm) and International Political Economy IPE (www.lib.uconn.edu/ 〜 mboyer/syl216.html), as well as the role he played in developing a state-of-the-art 30 workstation classroomthe first computerized teaching facility for the social sciences on the University of Connecticut campus. Boyer's efforts, however, are not limited to university students at Storrs. He has long worked to develop and deliver computer-assisted, Internet-based international studies simulations at the college, high school and middle school levels. Through his continued collaboration with Project ICONS (University of Maryland), a project he worked on in the 1980s under the direction of Jonathan Wilkenfeld, he links students around the world so they may receive training in international negotiation, policy analysis, conducting computer research, and using communications technologies. His continuing collaborative efforts with the ICONS group resulted in 1999 in the publication of a new Rowman \& Littlefield book on international negotiation, Negotiating a Complex World (coauthored with Brigid Starkey and Jonathan Wilkenfeld), which lays out new approaches to teaching negotiation concepts (www.icons.umd.edu/negotiating/).

Boyer has received Eisenhower and Connecticut Collaborations grants to develop Internet-based simulations for use in inner-city schools. He also participates in the Neag Center for Gifted and Talented Education's summer teacher training institute, helping veteran teachers develop innovative teaching techniques. His classroom skills earned him a 1992-93 Pew Faculty Fellowship in International Affairs from Harvard's Kennedy School of Government. Boyer has also had extensive involvement in the University of Pittsburgh's International Affairs Network, conducting workshops for scholars from Central and Eastern Europe.

It is probably not surprising that Boyer has undertaken the delivery of the first web-based supplemental international text, WebQuester: International Relations, a sample of which can be found at www.dushkin.com/webquester/. Or that, to accompany his coauthored print international relations textbook, World Politics (3rd ed., Duskin/ McGraw-Hill, 2000), he developed the first web site directly tied to a college level text that includes a wide array of interactive exercises, problem-based learning exercises and weekly topical updates. He was recently named editor of the International Studies Association's newest journal, International Studies Perspectives, whose web site and mission statement are located at www.

lib.uconn.edu/ $\sim$ mboyer/ ispindex.html.

It is hard to imagine a political scientist who would better exemplify the spirit of the Rowman \& Littlefield Award. An exemplar of the professor who blends research and teaching in the classroom, Mark Boyer has improved the abilities of students from middle schools through doctoral programs, both here and abroad, to compete in the increasingly global marketplace. He has raised the bar for integrating international relations, the classroom, and technology. In doing so, Mark Boyer has done his students and the discipline of political science proud. 